\title{
The Status of the 'Progressive Aspect' in the Hellenistic Greek of the New Testament
}

\author{
Věnováno k uctění památky mého profesora Antonína Bartoňka
}

Vit Bubenik

(Memorial University of Newfoundland, St. John's)

\begin{abstract}
In this paper, I want to revisit the issue of the status of the 'progressive aspect' in Hellenistic Greek which I have dealt with in the Encyclopedia of Ancient Greek and Linguistics (2014: pp. 346-350). The entire issue is placed within the contexts of (i) larger cross-linguistic evidence for the existence of the progressive aspect in other Indo-European languages, and (ii) language contact of the colloquial Syro-Palestinian variety of Hellenistic Greek with Aramaic and Hebrew. It is shown that the verbal system of Hellenistic Greek included innovative analytic formations coexisting with aspectual and temporal categories inherited from Classical Greek.
\end{abstract}

\section{Keywords}

compound tenses; progressive aspect; analytic formations; Hellenistic Greek; Aramaic; Hebrew; New Testament

During the period of Hellenistic Greek we witness the rise and spread of numerous analytical formations in the verbal system, specifically in the imperfective aspect (Present and Imperfect) and in the perfect (Perfect, Pluperfect), see Aerts (1965), Bubenik (2010). This tendency continued through the medieval period and ultimately it resulted in a complete rebuilding of the perfect system. In parallel with other new Indo-European languages Modern Greek ended up with analytic formations by combining the auxiliary $\varepsilon " \chi \omega$ ['exo] 'I have' with the infinitive ( the passive participle in dialects ( $\varepsilon^{\prime} \chi \omega \lambda \nu \mu \varepsilon^{\prime} v o$ ['exo li'meno]). It goes without saying that this process of restructuring the synthetic morphology of the perfect (retrospective) aspect lasted centuries (diatopic and diachronic details are available in Moser 1988).

However, unlike some new Indo-European languages, Medieval and Modern Greek have not paradigmatized the periphrastic formations of Hellenistic Koine (available in New Testament) which combine the copula with the present participle of the type ciui / ๆ๊ $\lambda \hat{u} \omega v$ 'I am / I was loosening'. Grosso modo, these formations correspond to the progressive (continuous) aspect of several Western and Eastern Indo-European languages: 
English, Spanish, Lithuanian, Hindi (without trying to be exhaustive): 'I am / was working'.

(1) (English) I am working (Progressive Present)

I was working (Progressive Past)

(Spanish) estoy trabajando (Progressive Present)

estaba trabajando (Progressive Past)

(Lithuanian) esù be-dirb-ãs $(\mathrm{M})$ be-dirb-ánti (F) (Progressive Present)

buvaũ be-dirb-ãs (M) be-dirb-ánti (F) (Progressive Past)

(Hindi) cal rah-ā hūm (M), rah-ī hūm (F) 'I am going' (called Continuous Present) cal rah-ā th-ā (M), rah-ī th-ī (F) 'I was going' (Continuous Past)

It will be observed that English may form the progressive aspect even in the prefect ( $I$ have been working) but Spanish cannot (*estuve trabajando). The present participle in English and Spanish is not marked for gender but the 'more conservative' East IndoEuropean languages (Lithuanian and Hindi) do so. The continuous aspect in Hindi attaches the participial form of rah-nā 'stay, remain' to the root cal 'go' (hence the marking for gender in $r a h-\bar{a}$ vs. $r a h-\bar{\imath}$ ); in the past continuous the gender is double-marked since the past form of the copula is based on the grammaticalized participle of the lexical verb sth $\bar{a}$ - 'stand' $($ sthi-ta $>t$ th $\bar{a}>t h \bar{a})$. Another fairly well known type of forming the progressive aspect is found in Arabic which combines the copula (in the Perfect) with the finite form of the main verb in the Imperfective (kān-a ya-ktub-u lit. he-was $3 / \mathrm{Sg}$ / M+write+IPFV 'he was writing').

In New Greek dialects the compound forms of the copula and the present participle are only found in Tsakonian (émi orú (M), orú-a (F) 'I see'; éma orú (M), orú-a 'I saw'). Here they function as a simple present and imperfect, i.e. not as the progressive aspect (the simple uncompounded forms are used only in modal meaning after the particle na, e.g. na ftén- $u$ 'that I make', na ftén-ere 'that you make'). In other words in Tsakonian the progressive aspect was grammaticalized as the tense category (they could be traced

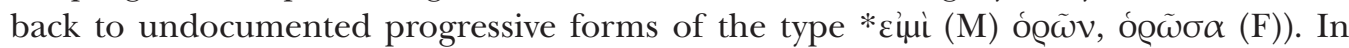
this context it should be mentioned that in the extinct dialect of Propontis the aorist was formed analytically by combining the perfect participle with the copula [gravó ma] 'I

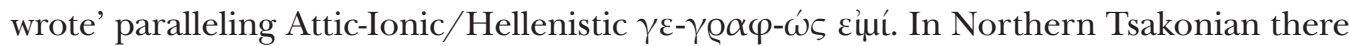
are traces of the use of the perfect participle instead of the present participle as in [emi

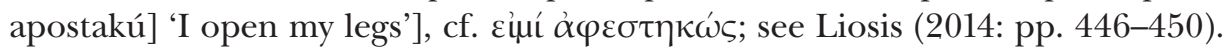

The changes which were taking place during the Hellenistic period were due to language-internal and external factors. Language-internal changes during this period were studied in many works; on the other hand, language external-factors have been elevated to a systematic study much more recently; see Hickey (2010) for the essentials of contact explanations in linguistics (convergence, grammaticalization, borrowing and code- 
switching). Our enterprise is demanding in that it involves early contact scenarios where in the absence of living speakers we have to rely on written documents (papyri, biblical texts, inscriptions): namely, the contact of Hellenistic Koine with Coptic in Egypt, Hebrew and Aramaic in Palestine and Syria, and other languages in newly settled areas of Asia Minor (cf. Bubenik 1989, 2010).

In what follows we will concentrate on the 'colloquial' variety of the Hellenistic Koine - the Greek of the New Testament, a collection of 27 short works written by men without a higher education during the $1^{\text {st }} \mathrm{CE}$. The two 'classics' dealing with the rise of periphrastic formations in the imperfective aspect are the monographs by Björck (1940) and Aerts (1965) and there are extensive sections on 'periphrastic conjugations' in the grammar of the NT Greek by Blass \& Debrunner (1961, 1990), earlier grammars of the Old Testament Greek (Thackeray 1909) and the NT Greek (Moulton \& Howard 1938), and later special studies (Fanning 1990, McKay 1994); for the papyri one has to consult Palmer (1946) and Gignac (1981). In what follows the NT data are quoted according to Nestle (1921).

In terms of their documentation Blass \& Debrunner (1961: p. 179) observe that the periphrasis is rare in the present, while the periphrases in the imperfect, future, infinitive and even the imperative are 'widely employed' in the NT.

An example of the periphrasis in the present is found in the 2 Corinthians [9.12]:

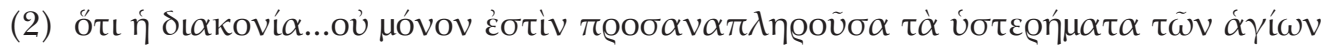
'for the rendering of this service not only supplies the wants of the saints' (instead of the finite form $\pi \varrho 0 \sigma \alpha v \alpha \pi \lambda \eta \varrho 0 \tilde{)})$

The examples of the periphrasis in the imperfect are plentiful; salient examples are in (3):

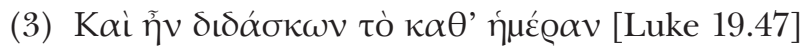

'And he was teaching daily'

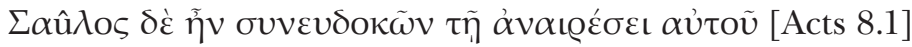

'And Saul was consenting to his death'

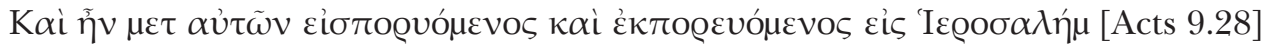

'And he was entering and exiting with them in Jerusalem'

(King James Bible 1611/1952 translates the progressive aspect by the simple past/ preterit: 'So he went in and out among them at Jerusalem')

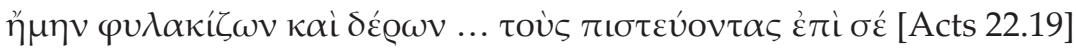

'I was imprisoning and beating those who believed in you'

(King James 1611/1952: 'I imprisoned and beat those who believed in you') 
It will be observed that English with its progressive aspect possessed grammatical means to capture the progressive aspect of the NT. Earlier translators, however, did not hesitate to violate the rules of their languages by calquing their translations on the Greek original. St. Jerome in his translation into Latin (3') simply combined the copula with the present participle found in the Greek original:

(3') Et erat docens quottidie

Saulus autem erat consentiens neci eius

Et erat cum illis intrans et exiens in Ierusalem

Ego eram concludens in carcerem et caedens eos, qui credebant

Similarly, the translator into Old Slavic (Old Church Slavonic) calqued his translation of Luke (19.47) by combining the copula in the aorist with the present participle: И бњ оучл по всл дни (the modern Bulgarian translation, however, displays the monolectal form of the imperfect И поучаваше вськи день).

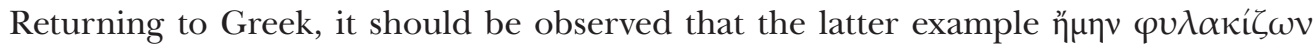

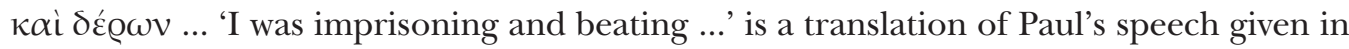
Aramaic ('E $\beta \varrho \alpha ́ ı \delta\llcorner\delta\llcorner\alpha \lambda \varepsilon ́ \kappa \tau \omega)$ and that its original could be in the periphrastic construction (progressive aspect) combining the copula and the participle. Unfortunately, the Aramaic originals of Hellenistic works (the Gospels according to Matthew and Mark (?), Joseph's Jewish Wars) have not come down to us but this construction is well documented in Hebrew and Aramaic biblical texts.

$\begin{array}{lll}\text { (4) hāyāh } & \text { Yōbē } \underline{\mathrm{d}} & \text { Pəộāmāh [Gen. } 4.2 \text { in Hebrew] } \\ \text { was } & \text { till+PRES PART } & \text { soil }\end{array}$

'He was tilling the soil'

(5) wə=kol $\quad \underline{\mathrm{d}} \overline{\mathrm{k}} \quad$ lā $l \varepsilon-h ə w \overline{\mathrm{e}}$ and=everybody who not $3 \mathrm{SgM}+\mathrm{be}+\mathrm{IPFV}$ do+PRES PART 'and anybody who will not be doing'

(6) Pənā həwētīi I be+PERF+1Sg stand+PRES PART

qāêem [Aramaic translation of Deuteronomy 10.10]

'I was standing' (but the Hebrew original displays a simple perfect עמדתי [Sāmadtī] 'I stood').

There are also instances of the periphrastic infinitival construction as in Luke [9.18] $\kappa \alpha i$

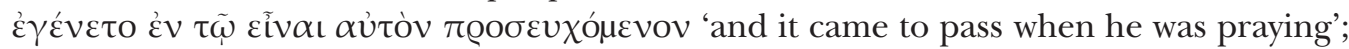
here the opening kai egéneto (Hebrew ויהי [wa-yahī]) followed by the articular infinitive corresponds to the Hebrew construction of ba + infinitive (בהיותו מתפלל [bi-hyōtō mithallēl]).

An example of the future tense periphrasis is in (7):

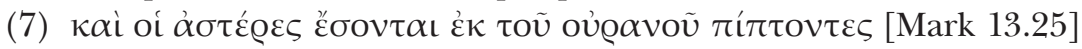


'and the stars will be falling from heaven'

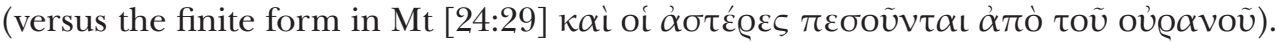

On the other hand, the future tense periphrasis with $\mu \varepsilon \dot{\lambda} \lambda \lambda \omega$ 'intend to do, be about to do' continues the construction amply documented at the two previous stages of Ancient Greek (Homeric and Classical). Strictly speaking, we are not dealing with a periphrastic tense but an inceptive aspect: contrast the sigmatic future $\lambda \dot{\sigma} \sigma \omega$ 'I will loosen' with the inceptive $\mu \varepsilon \dot{\lambda} \lambda \omega \lambda v_{\varepsilon} \varepsilon v$ 'I intend / I am about to loosen'. This construction can also express the future in the past as in Luke [7.2] $\eta \mu \varepsilon \lambda \lambda \varepsilon \tau \varepsilon \varepsilon \varepsilon \varepsilon v \tau \tilde{\alpha} v$ 'he was at the point of death' (cf. Latin erat moritürus) which is impossible with the simple future. This construction also replaces the disappearing non-finite forms of the infinitive $\lambda \dot{\sigma \varepsilon \varepsilon} v$ and the

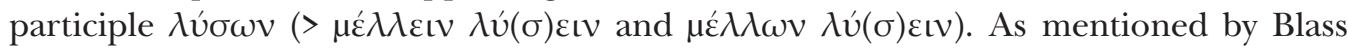
\& Debrunner (1961: p. 181) one of the advantages of the analytic construction was its ability to be used in the absolute construction to indicate relative time where the future

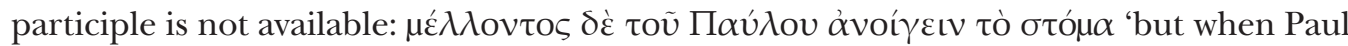
was about to open his mouth' [A 18:14], cf. the Latin absolute construction with the present participle incipiente autem Paulo aperire os (but the future participle cannot be used

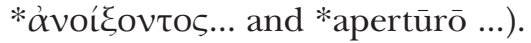

The status of analytic formations involving the imperfective participle remains contentious. Its beginnings, as discussed by Aerts (1965: pp. 5-26), lie in pre-Hellenistic Classical Greek. Porter (1989: p. 478) concluded that "Semitic intervention into periphrastic constructions in the NT cannot be supported" but admits that "perhaps its use ... is aided by Septuagint precedent". More recently this issue was re-examined on the basis of the Septuagint (Pentateuch) by Evans (2001: p. 256). He cautiously concluded that of the 68 examples in the entire Greek Pentateuch over $57 \%$ of examples "closely imitate" similar Hebrew expressions, 28\% are "comparatively free" and nearly 15\% are free of any "formal motivation" from the Masoretic text. Given the fact that in the NT Greek only the combination with the copula in the past is relatively common (while that in the future is less common and in the present it is isolated), I have suggested (2010: p. 48) that it might be plausible to argue that the progressive aspect was "systematized" in the OT and NT Greek to a much higher degree than in any other work in a "literary" version of the Hellenistic Koine as a result of the influence from the Semitic background of their translators and authors. This is not to claim that its use reached the paradigmatic status which it possessed in contemporary Mishnaic Hebrew and Middle Aramaic. The same bilingual speaker in Aramaic (הוה מלמד [həwāh məlámmid] or [həwāh məlmmếd] 'he

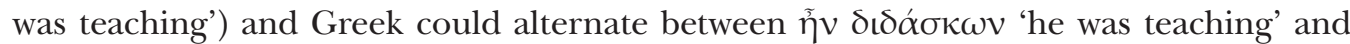

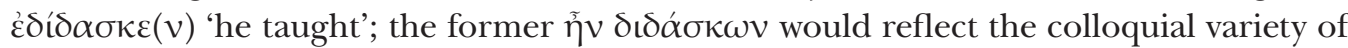
the regional Syro-Palestinian Koine, the latter $\dot{\varepsilon} \delta i \delta \alpha \sigma \kappa \varepsilon(v)$ would be used when the same speaker resorted to the more formal register of Hellenistic literary works. To provide a credible contemporary parallel, the overuse of the progressive aspect in Indian English (as in I am knowing it) reflects its larger scope in Indic languages (cf. Hindi maĩ use jāntā hũ I him/it know+PRES PART be+1Sg 'I am knowing him/it'). The relative frequency of the progressive aspect in the Egyptian (Ptolemaic) Koine can also be understood in 
terms of the influence from the New Egyptian substrate which possessed a number of periphrastic tenses. In any case, as emphasized by Evans (2001: p. 257), further research in this area has to come up with some "natural frequencies of occurrence in extra-Biblical Greek" to adjudicate properly the Pentateuch frequencies. Later on, during the Medieval period the progressive aspect was used "as an alternative expression of continuity" (Browning 1983: p. 38). However, the later development towards Modern Greek was not in the direction of the innovative analytic formation since no contemporary variety of Greek - with the exception of Tsakonian - systematized / paradigmatized it.

It is imperative to put the above discussion of the rise of analytic formations in the context of internal changes documented in the Classical language. Classical Greek had already made use of compounding in the formation of the mediopassive modal forms (subjunctive and optative). These formations are based on the mediopassive participle in $-\mu \varepsilon \dot{v}$ os in combination with the modal forms of the copula (in 8):

(8) Mediopassive Perfect Indicative $\lambda \dot{\varepsilon}-\lambda v-\tau \alpha \iota$

Mediopassive Pluperfect Indicative $\dot{\varepsilon}-\lambda \dot{\varepsilon}-\lambda v-\tau \mathrm{O}$

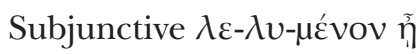

Optative $\lambda \varepsilon-\lambda v-\mu \varepsilon \dot{v}$ ov $\varepsilon$ ĭn

Already in the Classical language this periphrasis had been extended to the active modal forms combing the active perfect participle with the modal forms of the copula (in 9):

(9) Active Perfect Indicative $\lambda \varepsilon^{\prime}-\lambda v-\kappa-\varepsilon v$

Active Pluperfect Indicative $\dot{\varepsilon}-\lambda \varepsilon-\lambda \hat{u}-\kappa-\varepsilon \iota v$

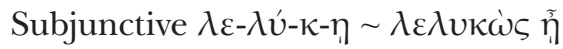

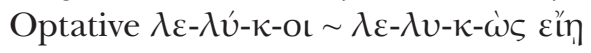

In Hellenistic Greek there are further extensions of periphrasis found in the formation of the following categories:

(a) The future perfect [both active $(\lambda \varepsilon-\lambda \hat{v}-\sigma-\varepsilon \iota)$ and mediopassive $(\lambda \varepsilon-\lambda \dot{v}-\sigma \varepsilon-\tau \alpha \iota)]$ :

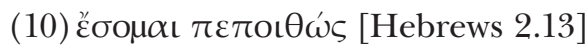

'I will put trust'

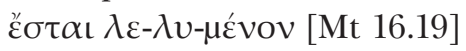

'It shall be loosed'

(i.e. not the synthetic passive future or $\lambda v-\theta \eta$ - $\sigma \varepsilon-\tau \alpha \iota$ or the mediopassive future $\lambda \varepsilon-\lambda v$ $\sigma \varepsilon-\tau \alpha \iota)$. It should be observed that in the active the future perfect can be formed only from the $k$-perfect ( $\varepsilon \sigma \tau \eta \dot{\xi} \omega$ [he-stế-k-s-ō]) while it cannot be formed from the ablaut perfect $\pi \dot{\varepsilon} \pi \mathrm{o} \theta \alpha$ 'I trust' (*pe-poíth-s-ō).

(b) The mediopassive perfect imperative $(\lambda \dot{\varepsilon}-\lambda v-\sigma o)$ :

A rare example of the passive imperative in the $2^{\text {nd }}$ person is found in the magic papyri:

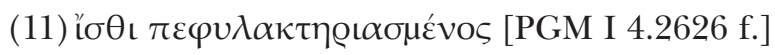


'be furnished with a phylactery'

(i.e. not the synthetic passive future $\pi \varepsilon \varphi v \lambda \alpha \kappa \tau \eta \varrho i ́ \alpha \sigma o)$.

An example for the $3^{\text {rd }}$ person imperative:

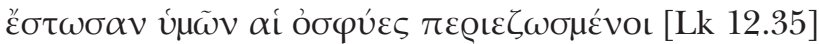

'let your loins be girded'

(c) The indicative forms of the mediopassive perfect and pluperfect $(\lambda \dot{\varepsilon}-\lambda v-\tau \alpha$ t and

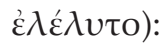

The analytic formations of the mediopassive perfect and pluperfect in the indicative are numerous but so are their synthetic counterparts. The perfect form $\gamma \dot{\gamma} \gamma \varrho \alpha \pi \tau \alpha$ เ

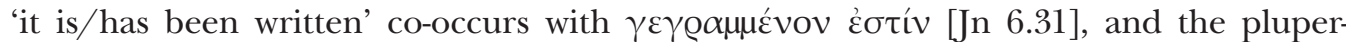

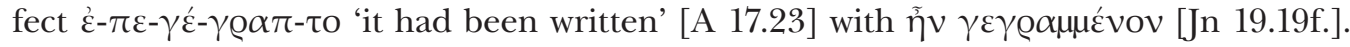
The combination of the participial form of the copula with the mediopassive participle ( $\gamma \varepsilon \gamma \varrho \alpha \mu \mu^{2}$ ov óv) can express the passive progressive "to express still more forcibly the persistence of the new state of things" (Blass \& Debrunner 1961):

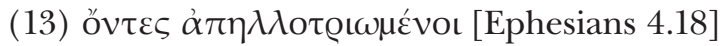

'(being) alienated'

(d) The active pluperfect forms (ท̃ $v \lambda \varepsilon \lambda v \kappa \omega ́ s)$ :

Examples of the analytic active pluperfect formations based on the active perfect participle competed with those based on the aorist participle which existed in the classical

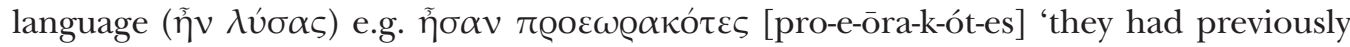

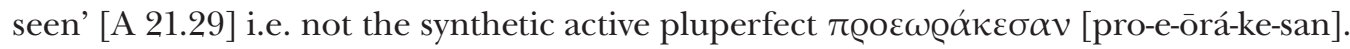
In the NT Greek the earliest examples of the periphrasis with the aorist participle are documented in the passive (cf. Blass \& Debrunner 1961: p. 180):

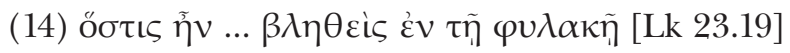

'who had been thrown into prison'

Summarily, while we can portray the Classical verbal system as based on the three-way aspectual opposition and a temporal opposition of past versus non-past (with an aspectual future realized as a perfective non-past), we can portray the innovative aspectual system of the early Christian literature represented by the NT as possessing a three-way opposition of tense (Present, Past, Future) with an additional progressive aspect. The construc-

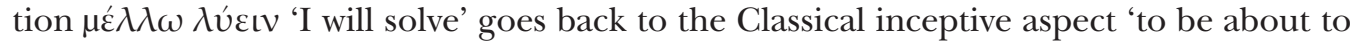
do' but it can also be used as an analytic future (Modern Greek future continues another volitional construction $\theta \varepsilon \dot{\lambda} \omega$ (I want) $\lambda v ́ \varepsilon \iota v$ (INF) 'I want to solve' > $\theta \alpha$ (FUT) $\lambda u ́ \sigma \omega$ (I solve) 'I will solve').

While the active perfect forms were still very much around we also noticed the periphrasis for the pluperfect based on the aorist participle $\tilde{\eta} v \lambda \hat{v} \sigma \alpha \varsigma$; in the mediopassive 
perfect the analytic formations in the indicative competed successfully with the inherited synthetic forms.

Table 1: Tense/Aspect system of Classical Greek and the Innovative Formations of Hellenistic Greek

\begin{tabular}{|c|c|c|c|}
\hline Active & Present & Past & Future \\
\hline Imperfective & $\lambda \dot{v}-\omega$ & $\stackrel{\varepsilon}{\varepsilon}-\lambda v-O v$ & $\lambda \dot{v}-\sigma-\omega$ \\
\hline Perfective (Aorist) & $\stackrel{\varepsilon}{\varepsilon}-\lambda v-\sigma \alpha$ & & \\
\hline Perfect & $\lambda \varepsilon^{\prime}-\lambda v-\kappa-\alpha$ & $\dot{\varepsilon}-\lambda \varepsilon-\lambda \dot{v}-\kappa-\eta$ & $\lambda \varepsilon-\lambda \dot{v}-\sigma-\omega$ \\
\hline $\begin{array}{l}\text { Med-Pass Perfect } \\
\text { Indicative }\end{array}$ & $\lambda \varepsilon^{\prime}-\lambda v-\tau \alpha \iota$ & $\dot{\varepsilon}-\lambda \dot{\varepsilon}-\lambda v-\tau O$ & $\lambda \varepsilon-\lambda v^{\prime}-\sigma \varepsilon-\tau c$ \\
\hline
\end{tabular}

Innovative Analytic Formations of Hellenistic Greek

\begin{tabular}{|c|c|c|}
\hline Progressive & 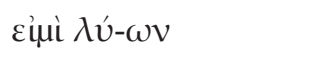 & 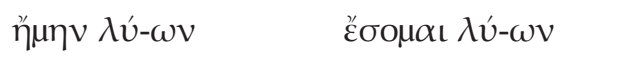 \\
\hline Inceptive $>$ Future & $\mu \varepsilon \dot{\varepsilon} \lambda \lambda \omega \lambda \dot{v}-\varepsilon \iota \nu$ & 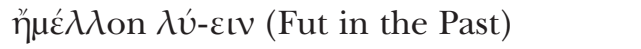 \\
\hline Med-Pass Perfect & 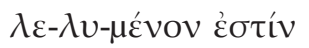 & 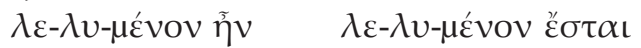 \\
\hline
\end{tabular}

We should also notice the innovative middle voice forms of the copula in the past $\eta \mu \eta v$,

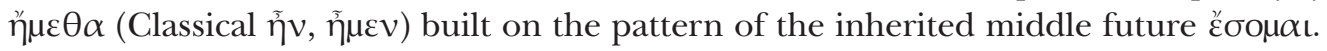

\section{Bibliography}

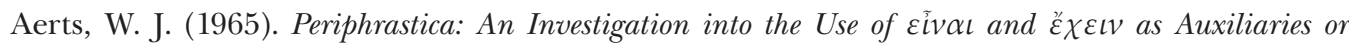
Pseudo-Auxiliaries in Greek from Homer up to the Present Day. Amsterdam: Hakkert.

Björck, G. (1940). HN $\triangle I \triangle A \Sigma K \Omega N$ (Ên didáskōn). Die periphrastischen Konstruktionen im Griechischen. Uppsala: Almqvist \& Wiksell.

Blass, F., \& Debrunner, A. (1961). A Grammar of the NT and Other Early Christian Literature (Transl. R. W. Funk). Chicago: University of Chicago Press.

Blass, F., \& Debrunner, A. (1990). Grammatik des neutestamentlichen Griechisch (17. ed.). Göttingen: Vandenhoeck und Ruprecht.

Browning, R. (1983). Medieval and Modern Greek. Cambridge: Cambridge University Press.

Bubenik, V. (1989). Hellenistic and Roman Greece as a Sociolinguistic Area. Amsterdam: Benjamins.

Bubenik, V. (2010). Hellenistic Koine in Contact with Latin and Semitic Languages during the Roman Period. Studies in Greek Linguistics, 30 (ed. by Chr. Tzitzilis et al., Thessaloniki), 32-54.

Bubenik, V. (2014). Compound Tenses (Hellenistic Greek). In G. Giannakis et al. (Eds.), Encyclopedia of Ancient Greek Language and Linguistics (pp. 347-350). Leiden: Brill.

Evans, T. V. (2001). Verbal Syntax in the Greek Pentateuch: Natural Greek Usage and Hebrew Interference. Oxford: Oxford University Press.

Fanning, B. M. (1990). Verbal Aspect in New Testament Greek. Oxford: Clarendon Press. 
Gignac, F. T. (1981). A Grammar of the Greek Papyri of the Roman and Byzantine Periods. Milan: Ist. ed. cisalpino La Goliardica.

Hickey, R. (Ed.). (2010). The Handbook of Language Contact. Malden, Mass.: Wiley-Blackwell.

Liosis, N. (2014). Tsakonian. In G. Giannakis et al. (Eds.), Encyclopedia of Ancient Greek Language and Linguistics (Vol. 3; pp. 446-450). Leiden: Brill.

McKay, K. L. (1994). A New Syntax of the Verb in New Testament Greek: An Aspectual Approach. New York: Lang.

Moser, A. (1988). The history of the perfect periphrases in Greek (Ph.D. diss. University of Cambridge).

Moulton, J. H., \& Howard W. F. (1938). A Grammar of New Testament Greek. Edinburgh: Clark.

Nestle, E. (1921). Novum Testamentum Graece et Latine. Stuttgart: Württemberg. Bibelanstalt.

Palmer, L. R. (1946). A Grammar of the Post-Ptolemaic Papyri. London: Oxford University Press.

Porter, S. E. (1989). Verbal Aspect in the Greek of the New Testament, with Reference to Tense and Mood. New York: Lang.

Preisendanz, K. (Ed.). (1928, 1931). Papyri Graecae Magicae (2 Vols.). Lepzig-Berlin: Teubner.

Thackeray, H. S. J. (1909). A Grammar of the Old Testament in Greek according to the Septuagint. Cambridge.

Prof. Ph.Dr. Vit Bubenik, P.Ph., FRSC / vbubenik@mun.ca

Department of Linguistics

Memorial University of Newfoundland, St. John's, NL, A1B 3X9, Canada 
